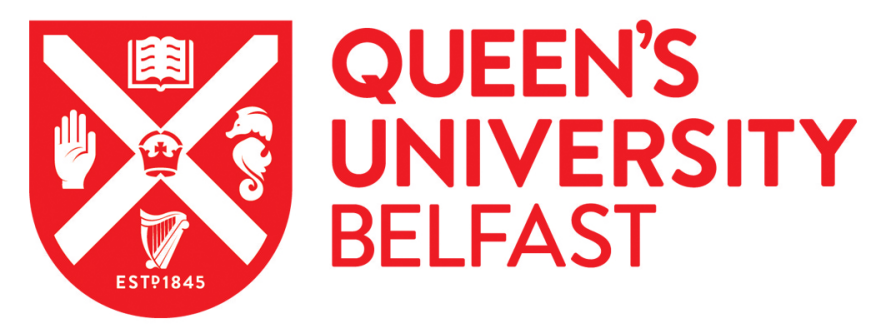

\title{
Field Measurements of a Full Scale Tidal Device
}

Jeffcoate, P., Starzmann, R., Elsaesser, B., Scholl, S., \& Bischoff, S. (2015). Field Measurements of a Full Scale Tidal Device. International Journal of Marine Energy, 12, 3-20. https://doi.org/10.1016/j.ijome.2015.04.002

Published in:

International Journal of Marine Energy

Document Version:

Early version, also known as pre-print

Queen's University Belfast - Research Portal:

Link to publication record in Queen's University Belfast Research Portal

Publisher rights

(C) 2015 The Authors

\section{General rights}

Copyright for the publications made accessible via the Queen's University Belfast Research Portal is retained by the author(s) and / or other copyright owners and it is a condition of accessing these publications that users recognise and abide by the legal requirements associated with these rights.

Take down policy

The Research Portal is Queen's institutional repository that provides access to Queen's research output. Every effort has been made to ensure that content in the Research Portal does not infringe any person's rights, or applicable UK laws. If you discover content in the Research Portal that you believe breaches copyright or violates any law, please contact openaccess@qub.ac.uk. 


\author{
Penny Jeffcoate ${ }^{\mathrm{a}}$, Ralf Starzmann ${ }^{\mathrm{b}}$, Bjoern Elsaesser ${ }^{\mathrm{a}}$, Stefan Scholl ${ }^{\mathrm{b}}$, Sarah Bischoff ${ }^{\mathrm{b}}$ \\ aueen's University Belfast, Stranmillis Road,Belfast BT9 5AG, p.jeffcoate@qub.ac.uk (Corresponding author) \\ +44 (0) 2890974012 \\ ${ }^{b}$ SCHOTTEL - Josef Becker Forschungszentrum GmbH, Mainzer Straße 99, 56322 Spay/Rhein, Germany, \\ RStarzmann@schottel.de
}

7

\title{
8 Abstract
}

9 Field testing studies are required for tidal turbine device developers to determine the 10 performance of their turbines in tidal flows. Full-scale testing of the SCHOTTEL tidal turbine 11 has been conducted at Queen's University Belfast's tidal site at Strangford Lough, NI. The 12 device was mounted on a floating barge. Testing was conducted over 48 days, for 288 hours, 13 during flood tides in daylight hours. Several instruments were deployed, resulting in an 14 expansive data set. The performance results from this data set are presented here. The device, rated to $50 \mathrm{~kW}$ at $2.75 \mathrm{~m} / \mathrm{s}$ was tested in flows up to $2.5 \mathrm{~m} / \mathrm{s}$, producing up to $19 \mathrm{~kW}$, when time-averaged. The thrust on the turbine reached $17 \mathrm{kN}$ in the maximum flow. The maximum system efficiency of the turbine in these flows reached 35\%. The test campaign was very successful and further tests may be conducted at higher flow speeds in a similar tidal environment.

Keywords: Tidal energy, tidal turbines, full-scale, field testing, performance assessment

22 Nomenclature and Abbreviations

23 ADP

24 ADV

$25 \mathrm{C}_{\mathrm{T}}$

$26 \mathrm{~d}$

$27 \mathrm{~d}_{\mathrm{h}}$

$28 \quad \mathrm{D}_{\mathrm{E}}$

$29 \mathrm{n}$

$30 \quad \mathrm{P}_{\mathrm{el}}$

31 PTO

32 RPM

33 STG

$34 \mathrm{~T}$

35 TEC

36 TSR

$37 \quad \mathrm{U}_{\text {in }}$

$38 \eta_{\text {system,i }}$
Acoustic Doppler Profiler

Acoustic Doppler Velocimeter

Coefficient of Thrust

Depth

Hub depth

Equivalent Diameter

Rotation rate

Electrical Power

Power Take-Off

Rotations per Minute

SCHOTTEL Tidal Generator

Thrust

Tidal Energy Converter

Tip Speed Ratio

Inflow velocity

System efficiency 


\section{Introduction}

40 The development of tidal energy converters and the advancement from lab-scale tests to prototype devices has accelerated in recent years. Many devices have been tank tested at model scales, such as Scotrenewables $1 / 40$ to $1 / 7$ scale tests [1] and Oceanflow 1/40 scale tests [2], and several have been deployed as full-scale devices; some examples of these are Andritz Hydro Hammerfest HS1000 [3], Alstom TGL DeepGen [4], Marine Current Turbines SeaGen [5], Verdant Power KHPS [6], Atlantis Resources AR1000 [7] and Scotrenewables SR250kW [8]. One of the key features for device developers to understand is how their turbine performs in 'real' turbulent tidal flows compared to laboratory flows [9]. This can be assessed by deploying a medium- or full-scale device in tidal field studies.

Queen's University Belfast recently conducted a series of experiments to determine the effect of tidal flows on 1/10 scale devices [10], as well as testing the scale models of Oceanflow's Evopod device [2], and in doing so developed a tidal test centre in Strangford Lough, which has flow speeds up to $2.5 \mathrm{~m} / \mathrm{s}$. SCHOTTEL also recently conducted model scale towing tank tests as well as pushing tests of their full-scale device [11] and wished to develop their understanding of the turbine's performance in tidal flows at full-scale.

During the summer of 2014, Queen's University Belfast, SCHOTTEL and Fraunhofer IWES collaborated under the EU MaRINET project to conduct a series of field tests of a full-scale tidal turbine in highly turbulent flows in Strangford Lough, N.I. The full scale device, the SCHOTTEL Tidal Generator (STG), was designed and constructed by SCHOTTEL and deployed at the QUB tidal test facility from June through to September. The $4 \mathrm{~m}$ turbine, rated at $50 \mathrm{~kW}$, operates from flow speeds of $0.8 \mathrm{~m} / \mathrm{s}$ and reaches maximum power at $2.75 \mathrm{~m} / \mathrm{s}$, so was operational at the QUB site. The turbine characteristics, inflow conditions and loading on the structure and rotor were all measured and used to calculate the performance characteristics of the turbine.

The testing method and turbine performance characterisation were guided by the IEC62600200 Technical Specification for Tidal Energy Converter (TEC) power performance assessment [12]. Several parts of the IEC TS standard were used for reference, particularly in terms of data processing, though there were several sections that differed from the testing performed. The TS is useful as a tool because it provides guidelines on techniques such as device placement, filtering and depth-averaging velocities, along with many testing methods. The main advantages of using the TS is that it gives a good basis for testing methods and data analysis techniques employed, and it also allows different devices to be directly compared in terms of site characteristics, turbine performance and operation. There are specific requirements for reporting the site conditions; however, this paper will focus on the turbine performance and output, rather than the site itself. Clauses of the TS used will be indentified in the text.

The key objectives of this paper are: to present a vessel-mounted testing method for field studies of medium- and full-scale tidal devices; to investigate the performance of a full-scale 
the tidal field site characteristics; the turbine description; the full-scale field testing method and equipment at the tidal field site; and the measured turbine performances.

\section{Site and test conditions}

The QUB tidal site in Strangford Lough is along the Eastern shore of Strangford Narrows. The test vessel, a dump barge, was moored at approximately $54^{\circ} 22.9 \mathrm{~N} 005^{\circ} 33.3 \mathrm{~W}$ [13], shown in Figure 1. The depth contours of the site are shown; however, for clarity of the plateau where the mooring was located the contours are limited to $30 \mathrm{~m}$ depth. The deepest part of the channel reaches $60 \mathrm{~m}$.
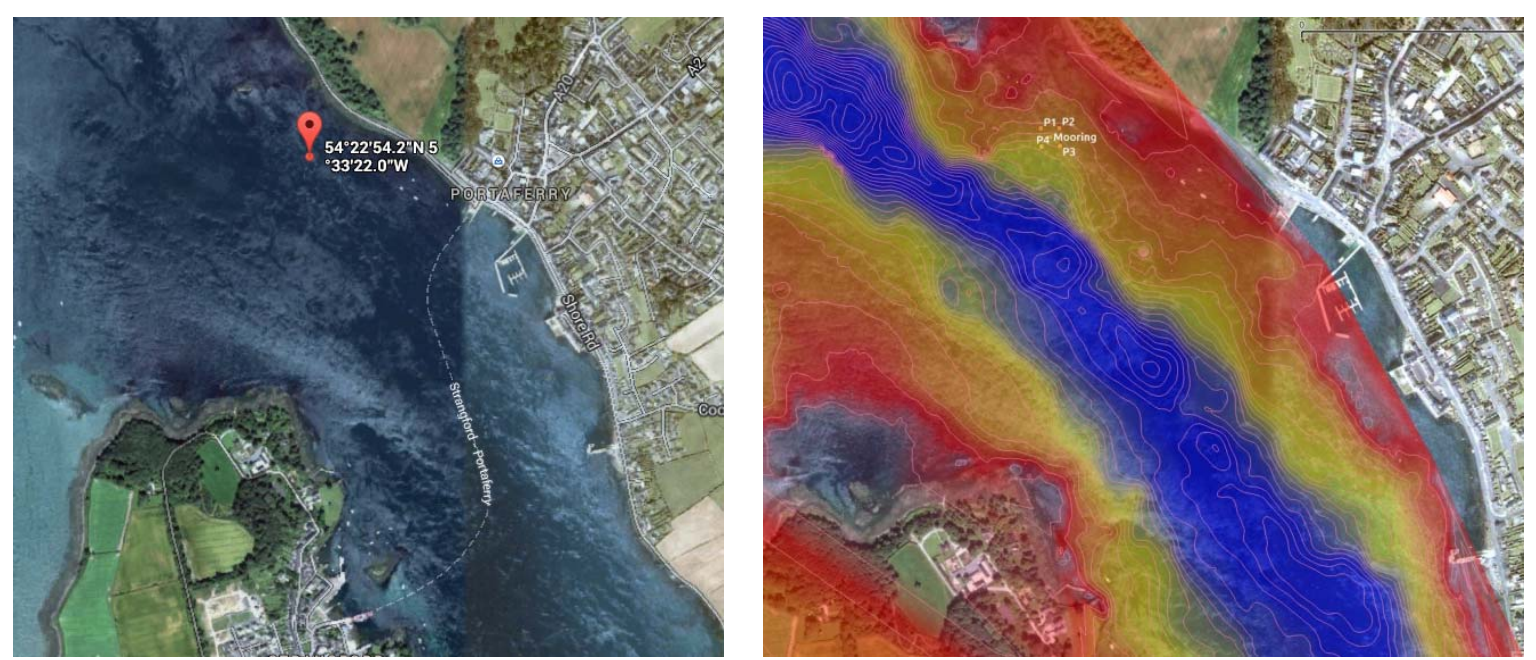

Figure 1: Location of mooring - left: Lat/Lon, right: Depth contours (blue $-30 \mathrm{~m}$, red 0m)

The lowest astronomical tide (LAT) with respect to chart datum on Admiralty Chart 2159 is $10 \mathrm{~m}$; however, the bed contour resolution is low so the depth was independently checked using barge mounted sonar. Using sonar data the lowest tide height at springs during the test period was $9.6 \mathrm{~m}$. The maximum water depth recorded was $15.8 \mathrm{~m}$. The range at the site was not however $6.2 \mathrm{~m}$; the barge was attached to a mooring that allowed it to swing over different parts of the bed depending on the tide (i.e. slack water or full flow) and wind direction. It can also be noticed that the depth to chart datum varies by $4 \mathrm{~m}$ over the tracks, hence the large range in sonar depth recordings.

Three example tracks of the barge movement are shown in Figure 2. These show that the barge swings about the mooring during the ebb and flood tides. A small amount of the ebb is shown on these plots and the movement during Low Water can be seen. The mooring extends out during ebb flow, and then moves towards the centre of the track during slack water, when there is no thrust on the mooring. Once the turbine was operational and the flood tide accelerated the mooring extended in the opposite direction. This also shows that the main flow direction during flood tide was $135^{\circ}$ and during the ebb tide is $315^{\circ}$. During operation the barge position can swing by up to approximately $20 \mathrm{~m}$; this results in variations in the directionality about the mooring of approximately $10^{\circ}$. This means that there can be a $10^{\circ}$ variation in the inflow velocity condition at the mooring and at the barge, but since the ADP is mounted on the same vessel as the TEC the incoming velocity recorded is the same as that 
that is experienced by the turbine. Also, because the frequency and angle of the oscillations about the mooring is relatively low compared to the fluctuations in the incoming velocity, no correction has been applied for this barge movement.

111 Mounting the ADP on the same vessel as the TEC has the added advantage that the pitch, roll 112 and yaw of the vessel, and the extension of the mooring do not need to be accounted for in 113 post-processing, because the ADP and TEC are on the same reference frame. This would be 114 more complex if a bed mounted ADP were used for quantifying the inflow velocity 115 condition. Also, because the depth changes over the tidal cycle, the bins covering the TEC 116 rotor area would change for a bed-mounted ADP, but does not for a vessel-mounted ADP, 117 meaning that data analysis has less inherent errors.

118 The variation in the depth can, however, have an effect on the inflow conditions in terms of 119 the turbulence intensity, shear profile and depth-averaged velocity. The shear profile will be 120 discussed in a Section 5.2, but unfortunately the differences in the profile cannot be accounted for in this data analysis. Since the ADP and TEC have the same support structure the power-weighted velocity will cover the TEC swept area regardless of depth, but the turbulence intensity may vary. This will be investigated in subsequent analysis and publications.

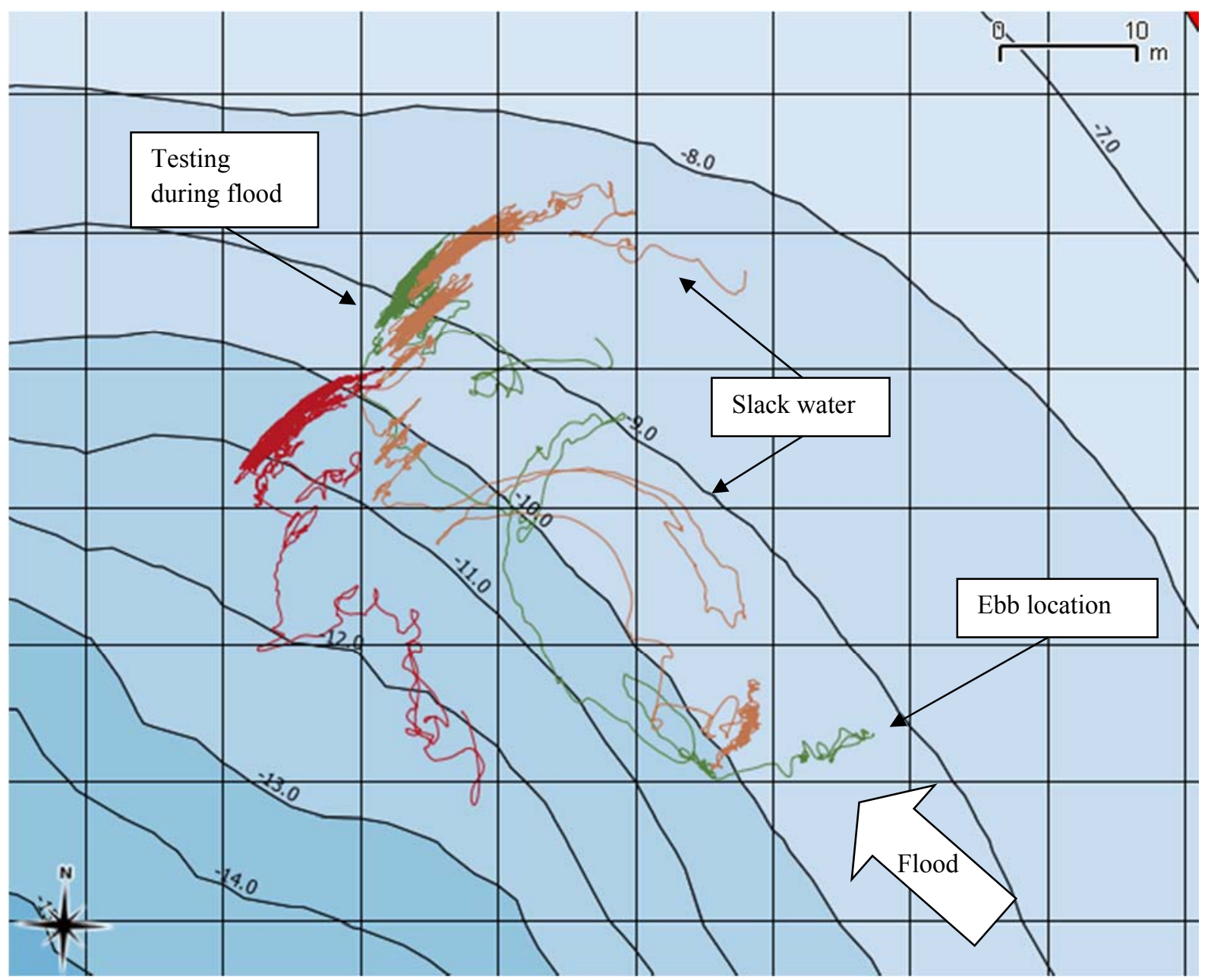


127 During the testing period the flood velocities varied from approximately $0.4 \mathrm{~m} / \mathrm{s}$ to $2.5 \mathrm{~m} / \mathrm{s}$.

128 The flow speed depended on the tide state, the range and the environmental conditions such 129 as the wind and atmospheric pressure; however, there was no detailed recording of these 130 conditions. The flow velocity alone was recorded, but was the correct incoming velocity for 131 the power assessment of the TEC so considered suitable for the analysis. During the ebb tide 132 the velocities did not exceed $1 \mathrm{~m} / \mathrm{s}$, due to the location of Walter Rock upstream from the site.

133 The tide ebbs either side of the rocks, creating an eddy at the test site location, with some 134 back flow. As a result, testing could only be conducted on the flood tide.

135 There is minimal wave action at the site, because of the surrounding topography and shelter. 136 The most significant wave action on the testing area is the local ferry wash, which has an 137 approximate wave height of $0.5 \mathrm{~m}$. Wave action was therefore not considered in the analysis.

\section{3. Investigated Turbine Design}

139 The STG features a rated electrical power of $50 \mathrm{~kW}$, a rotor diameter of $4 \mathrm{~m}$ at a rated inflow 140 velocity of $U_{\text {in }}=2.75 \mathrm{~m} / \mathrm{s}$. The layout of the STG is simple and robust, avoiding complex 141 subsystems. It consists of a fixed pitch three-bladed rotor, slow speed shaft, planetary gear 142 box and asynchronous generator, both cooled by the flow of ambient water (Fig. 3).

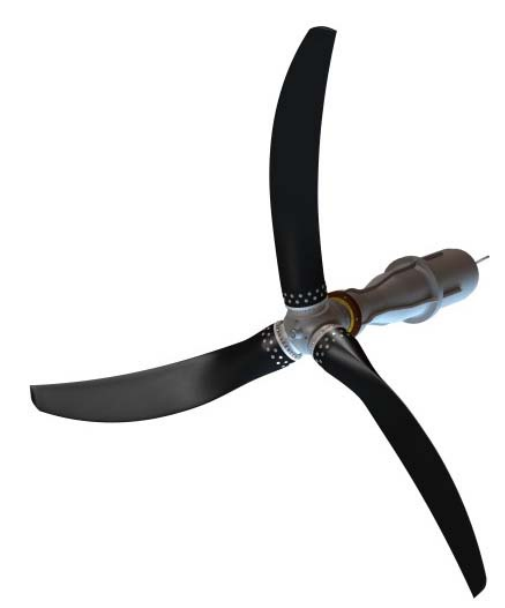

Figure 3: SCHOTTEL Tidal Generator STG - left: CAD model, right: Physical turbine

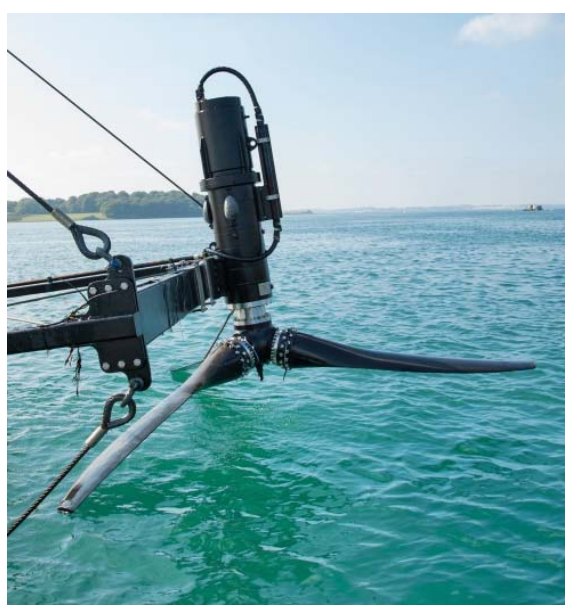

It has no active pitch mechanism and therefore the control system is very simple: after running at variable speed and capturing optimum power up to rated speed, the turbine goes into controlled overspeed as the flow velocity increases still further. The power taken from the turbine is kept constant while the rotational speed is increased. The general hydrodynamic design of the rotor blades aims for a reduced thrust coefficient, $C_{T}$, at higher tip-speed ratios $(T S R)$. To keep thrust forces in overspeed conditions low, passive-adaptive rotor blades out of carbon-fibre have been developed, as proposed by Nicholls-Lee [14] for example. These flex in overload conditions so that the pitch angle of the blades increases and the thrust forces are limited. This keeps the loads on the turbine, and especially on the support structure, low. Moreover, the cavitation inception can be delayed in overspeed conditions.

Prior to the sea trials, as discussed in this study, full-scale pushing tests as well as modelscale towing tank testing have been carried out to validate the STG blade design [11]. 
157 Furthermore, a complete drive-train has been installed in a submerged back-to-back 158 configuration and was subjected to extensive laboratory testing [15]. Two blade sets were 159 used in these tests: the commercial passive-adaptive blades and the rigid blades. These two 160 sets have the same hydrodynamic shape but a different structural design. In conditions below $1612.5 \mathrm{~m} / \mathrm{s}$ the blades perform similarly, but in larger flow speeds the passive-adaptive blades 162 reduce maximum power performance attainable but also significantly reduce the loading on 163 the rotor. At the QUB tests site flow speeds do not exceed $2.5 \mathrm{~m} / \mathrm{s}$, therefore the passive164 adaptive quality of the blades is not a necessary requirement. To better compare with smallerscale, model tests and numerical simulations described in [11] the rigid blade set was used in 166 this study. Further study of the difference between the two blade sets in this tidal environment 167 would be beneficial, but will be focussed on in future tests with higher flow speeds.

168 Figure 4 shows the main components of the drive train. The drive train consists of an 169 asynchronous machine, so it is necessary to energize the DC-link with an external power 170 source. This external power source was a diesel-electric engine (1) placed on the barge. The 171 turbine was controlled by a frequency inverter (2). Internally the frequency inverter consists 172 of three primary components: the rectifier (3), the output module (4) and the chopper module 173 (5). An on-board controller drives the output module, and therefore the turbine, by setting 174 different speed and torque values. As shown in Figure 4 the frequency inverter is used to 175 drive the generator. The inverter varies the speed of the generator and, therefore, the 176 generator terminal frequency. The inverter decouples the generator from the grid and makes it 177 possible to drive the generator at variable speed. The excitation voltage comes from a DC178 link. Since the STG operates with variable sped, a frequency inverter is needed. A three phase 179 choke (7) is connected in-between the output module and the generator to smooth the 180 electrical currents. If a defined threshold value in DC-link voltage is reached (650V) the 181 chopper is activated and the energy is discharged by the load bank (6).

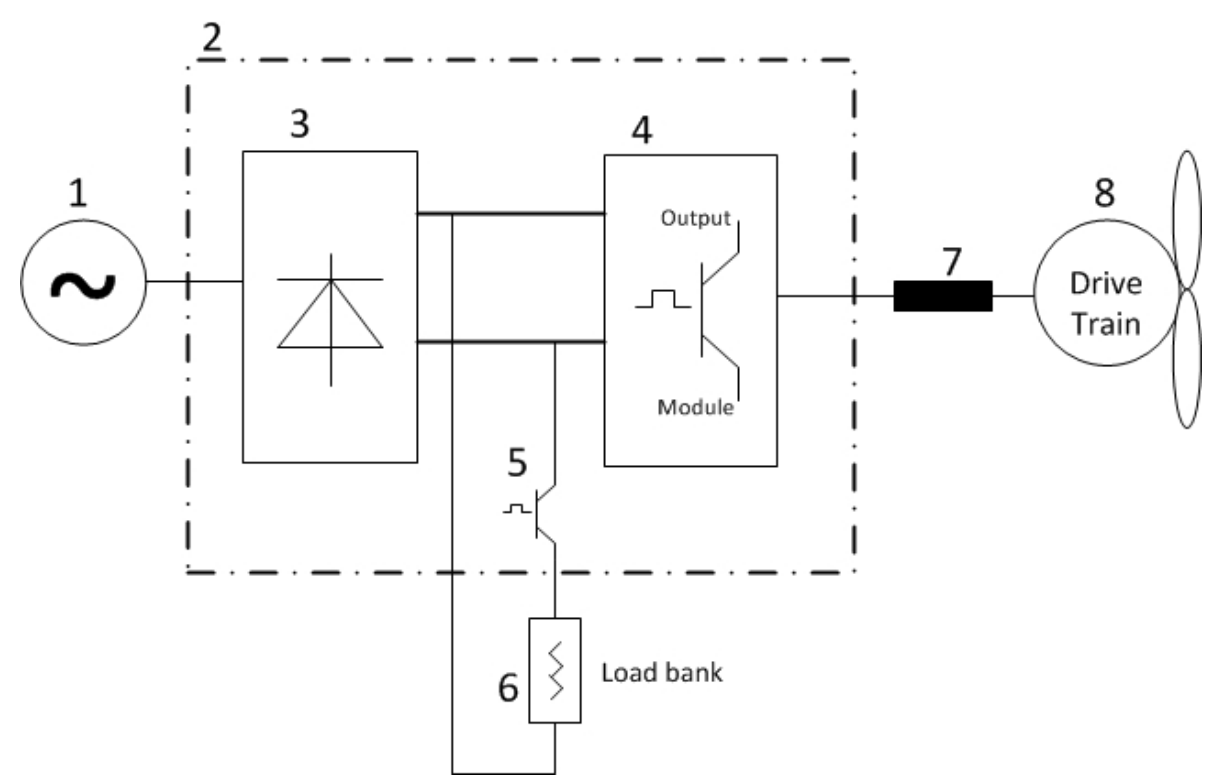

Figure 4: Power Take Off system - 1) Diesel-Electric engine, 2) Frequency Inverter, 3) Rectifier, 4) Output module, 5) Chopper module, 6) Load bank, 7) Chokes, 8) Drive train (Generator, Gearbox and Rotor blades) 
186 A summary of all relevant technical TEC parameters are summarised in Table 1, based on

187 [12, Subclause 6.2].

188 Table 1: Summary of TEC parameters

\begin{tabular}{|ll|}
\hline TEC make/type & SCHOTTEL STG \\
\hline TEC diameter [m] & 4 \\
TEC serial number & STG-000003 \\
TEC production year & 2014 \\
Rated power [kW] & 50 \\
Rated velocity [m/s] & 2.75 \\
Cut-in velocity [m/s] & 0.8 \\
Cut-out velocity [m/s] & 6 \\
Rotational speed range [rpm] & $15-190$ \\
\hline
\end{tabular}

189

190 4. Experimental Set-up

$191 \quad 4.1$ Mooring

192 The mooring used was a 4-point mooring with a riser. The main North and South anchors,

193 which took most of the mooring load, were 1.5ton fluked ship anchors and the East and West 194 anchors were $500 \mathrm{~kg}$ railway wheels. These were linked to $27.5 \mathrm{~m}$ chain to a single riser $8 \mathrm{~m}$ 195 long. Close to the surface the riser was linked to a $6 \mathrm{~m}$ rope bridle which was attached to the 196 port and starboard sides of the barge bow, described below.

1974.2 Barge layout

198 The STG turbine was mounted on a support frame suspended below a testing barge. The 199 barge was $10 \mathrm{~m}$ long by $4 \mathrm{~m}$ wide by $1 \mathrm{~m}$ high. The barge was $0.35 \mathrm{~m}$ submerged, giving a total 200 displacement of approx. 14ton. The turbine support was mounted on the stern of the barge 201 and attached to a lifting A-frame. Figures 5 and 6 show the turbine and frame in the testing 202 position and Figures 7 and 8 show the turbine and frame in the lifted position. The sensors 203 used during operation are also shown in Figure 5.

204 The turbine could be lifted clear of the water (between tests and for checks) and lowered for 205 operation. When lowered the turbine hub was $3.4 \mathrm{~m}$ below the surface so the blade tips swept 206 an area from $1.4 \mathrm{~m}$ to $5.4 \mathrm{~m}$ below the surface. The layout of the equipment on the barge deck 207 is shown in Figure 9. 




Figure 5: Schematic of barge with turbine in testing position - 1) TEC, 2) ADP, 3) ADV \& Sonar, 4) DGPS, 5) Load cell, 6) Electrical Cabinet, 7) Resistor Bank, 8) Generator, 9) Operations Room

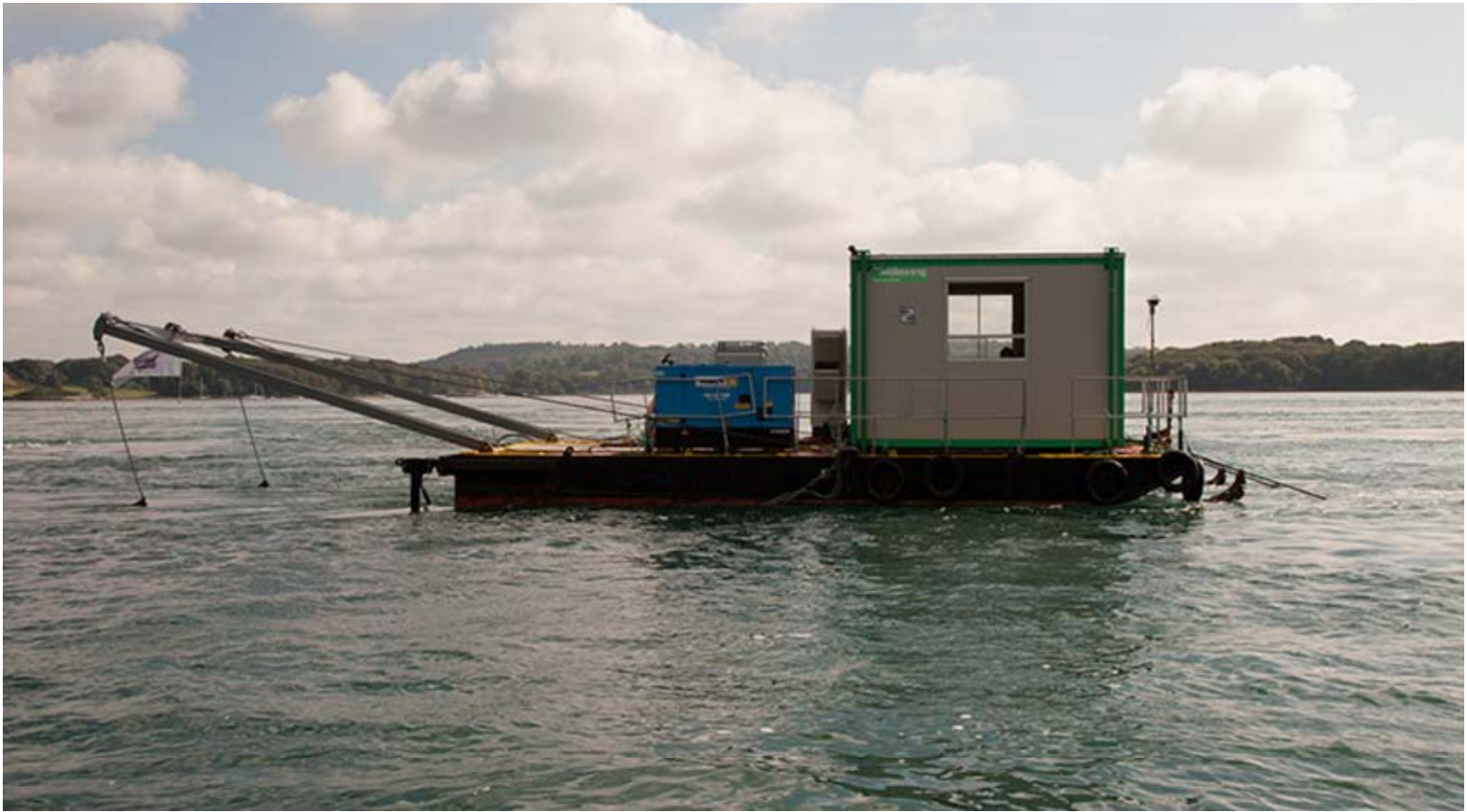






215

216

Figure 7: Schematic of barge with turbine in lifted position

217



Figure 8: Barge with turbine in lifted position 


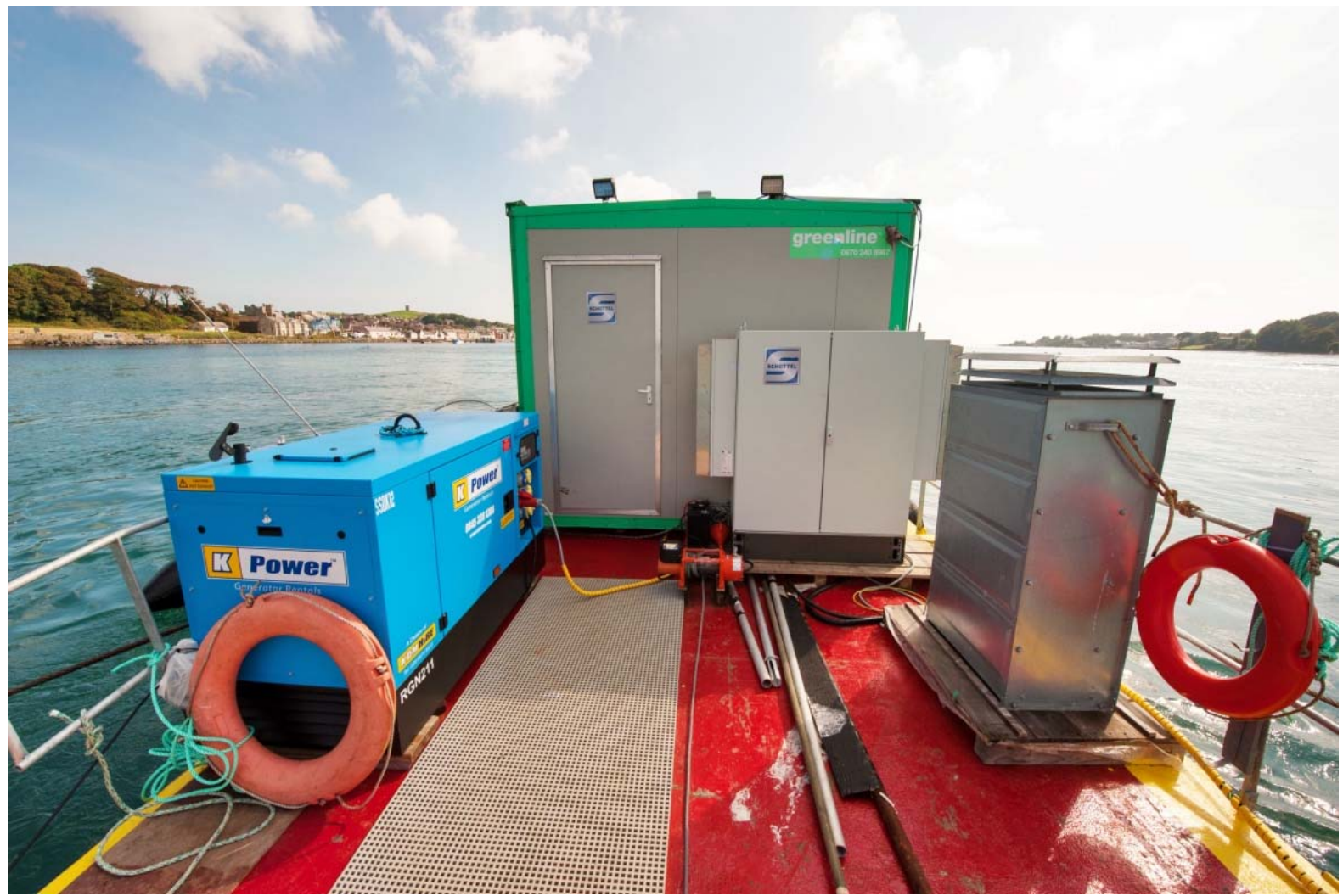

\subsection{Sensors and data acquisition}

223 There were numerous sensors on the turbine itself, the support frame and on the barge. All of the different sensors used on the barge are outlined below, with their main characteristics and outputs, to show the full scope of the data collection method; however, only some of the sensor measurements are used in this publication. Other data collected will be published in due course.

A control and data acquisition system (6-8) is used to collect instantaneous data from the turbine with a sampling frequency of $10 \mathrm{~Hz}$. The electrical power is measured using the response signal from the inverter. A speed sensor measures the rotational speed of the fast running shaft.

232 Mounted on the support structure there was a Nortek Aquadopp Acoustic Doppler Profiler 233 (ADP, 2) to measure the wake of the turbine at the hub height. This was orientated on the 234 support frame so that a single beam measured the velocity along the $x$ (streamwise) direction into the wake, to record the velocity deficit with distance from the turbine. Also mounted on the support frame were two load cells (5) to record the thrust on the frame and rotor. These were attached to the cables holding the turbine into the oncoming flow. The connection points are shown below in Figure 10. The load cells were connected to the port and starboard side of the barge via a rope connection point. 


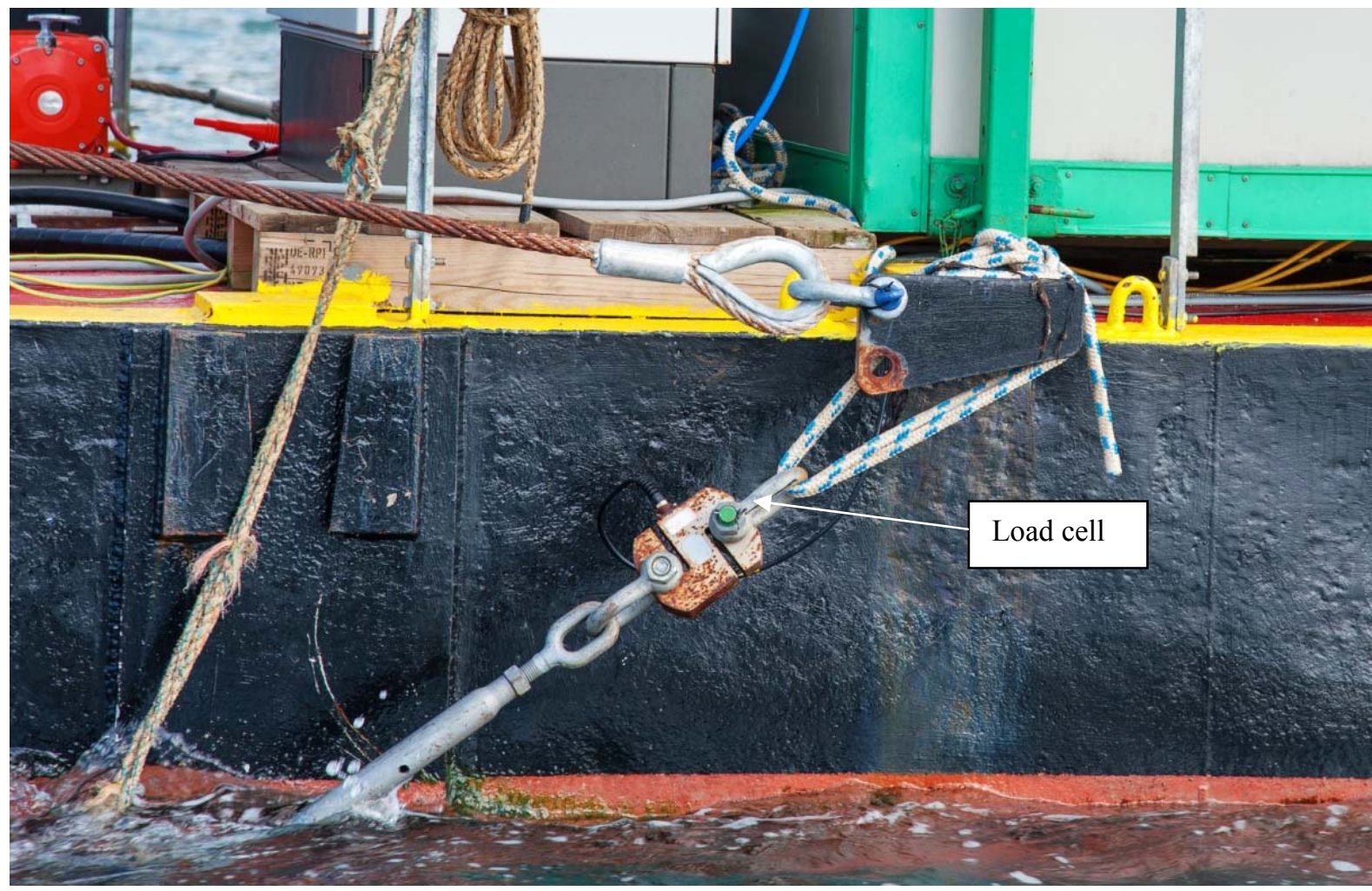

Figure 10: Load cell mounted on starboard side connected to turbine support frame

242 Mounted on the bow of the barge were an ADP (2), a Differential GPS (DGPS, 4) and

243 mounted on the starboard side of the bow were connection points for a second ADP, a Nortek

244 Vector Acoustic Doppler Velocimeter (ADV, 3) and a Rockland Scientific MicroRider.

245 The incoming flow conditions were measured using the ADP mounted on the barge bow, at $24610 \mathrm{~m}$, approximately $2.5 D_{E}$ (turbine diameters), directly upstream from the turbine centreline 247 (to IEC recommendation, Subclause 7.2). The recorded velocity was split into bins; the bin 248 size of the ADP was $0.2 \mathrm{~m}$, so that there were 20 bins covering the rotor area. Due to the beam 249 spread of $25^{\circ}$ of the ADP, the velocity is averaged over an area of $3.17 \mathrm{~m}$ diameter at rotor 250 midheight, which will give an approximate value over most of the rotor area. The power 251 weighted velocity across the projected capture area was calculated and used for quantifying 252 the inflow conditions.

253 A second ADP was mounted along the starboard side, at 2.25DE upstream of the turbine, but 254 with over $0.5 D_{E}$ lateral offset. This was used to determine the importance of the location of 255 the velocity measurement for testing the turbine performance.

256 The DGPS was used to record the position of the barge during operation, to determine if there 257 was any drift or excessive swing about the mooring. The second ADP, ADV and MicroRider 258 on the starboard side were deployed for one week to measure the inflow turbulence and 259 compare the effectiveness for each instrument type in inflow characterisation; these results 260 will be published separately. Below, in Table 2, is a summary of the equipment used during 261 this deployment. 
The data was collected using a Compact RIO and Labview system. The data was collected at

$26310 \mathrm{~Hz}$ (except the ADP which was $1 \mathrm{~Hz}$ ) and the turbine, load cell and velocity measurements 264 were synchronised. The uncertainties of each measured parameter used in subsequent 265 analysis in this paper are detailed below in Table 3.

266 Table 2: Summary of sensors in data acquisition

\begin{tabular}{|c|c|c|c|c|c|}
\hline Instrument & Manufacturer & Mounting & Measurement & $\begin{array}{l}\text { Data } \\
\text { Frequency }\end{array}$ & Characteristic \\
\hline $\begin{array}{l}\text { Speed } \\
\text { transducer }\end{array}$ & VS Sensorik & Drive shaft & RPM & $10 \mathrm{~Hz}$ & $\begin{array}{l}\text { Speed of turbine } \\
\text { Tip Speed Ratio }\end{array}$ \\
\hline Inverter & Schneider & Cabinet & $\begin{array}{l}\text { Electrical } \\
\text { power } \\
\text { Voltage } \\
\text { Electrical } \\
\text { current }\end{array}$ & $10 \mathrm{~Hz}$ & $\begin{array}{l}\text { Generated power } \\
\text { Power performance } \\
\text { Voltage } \\
\text { Electrical current }\end{array}$ \\
\hline Load cell & Althen & $\begin{array}{l}\text { Port and } \\
\text { starboard } \\
\text { sides }\end{array}$ & Load & $10 \mathrm{~Hz}$ & $\begin{array}{l}\text { Thrust on support } \\
\text { frame and turbine } \\
\text { Thrust performance }\end{array}$ \\
\hline $\begin{array}{l}\text { Aquadopp } \\
\text { ADP }\end{array}$ & Nortek & $\begin{array}{l}\text { Support } \\
\text { frame } \\
\text { Bow } \\
\text { centreline } \\
\text { Starboard } \\
\text { bow }\end{array}$ & $\begin{array}{l}\text { Inflow velocity } \\
\text { Inflow velocity }\end{array}$ & $1 \mathrm{~Hz}$ & $\begin{array}{l}\text { Wake } \\
\text { Power weighted } \\
\text { inflow } \\
\text { Power performance } \\
\text { Turbulence } \\
\text { comparison }\end{array}$ \\
\hline $\begin{array}{l}\text { Vector } \\
\text { ADV }\end{array}$ & Nortek & $\begin{array}{l}\text { Starboard } \\
\text { bow }\end{array}$ & Point velocity & $64 \mathrm{~Hz}$ & $\begin{array}{l}\text { Turbulence } \\
\text { comparison }\end{array}$ \\
\hline MicroRider & $\begin{array}{l}\text { Rockland } \\
\text { Scientific }\end{array}$ & $\begin{array}{l}\text { Starboard } \\
\text { bow }\end{array}$ & Turbulence & $2056 \mathrm{~Hz}$ & $\begin{array}{l}\text { Turbulence } \\
\text { comparison }\end{array}$ \\
\hline $\begin{array}{l}\text { Downscan } \\
\text { Sonar }\end{array}$ & Lowrance & $\begin{array}{l}\text { Starboard } \\
\text { bow }\end{array}$ & $\begin{array}{l}\text { Depth } \\
\text { Incoming } \\
\text { bodies }\end{array}$ & - & $\begin{array}{l}\text { Bottom tracking } \\
\text { Mammal recording }\end{array}$ \\
\hline
\end{tabular}

Table 3: Measured uncertainties

\begin{tabular}{|lll|}
\hline Measured parameter & Uncertainty component & Error \\
\hline \multirow{2}{*}{ Electric Power } & Current transformers & $\pm 3.3 \mathrm{~A}$ \\
Thrust & Variability of electric power & $\pm 3000 \mathrm{~W}$ \\
& Load cell & $<0.03 \%$ of end value $(3 \mathrm{ton})$ \\
& $\begin{array}{l}\text { Current profiler accuracy } \\
\text { Depth measurement relative to } \\
\text { Current Speed }\end{array}$ & $1 \%$ of measured value $\pm 0.5 \mathrm{~cm} / \mathrm{s}$ \\
& $\begin{array}{l}\text { performance surface } \\
\text { Wisalignment of performance surface }\end{array}$ & $\pm 1 \mathrm{~cm}$ (fixed brackets) \\
& with principal flow direction & $\pm 5^{\circ}$ (by sight) \\
\hline
\end{tabular}


272 There are several constraints on testing in a tidal field environment. Firstly, as described

273 previously, there is only sufficient flow speed on the flood tide at the site, so flood-only 274 operation was employed. The flood runs for two cycles of approximately 6 hours per day. At 275 this site operation is only during daylight hours, so only one flood cycle could be tested, 276 which led to 6 testing hours each day (provided the testing period was during daylight hours). 27748 days of testing over a 6 hour tide were conducted, which gave 288 hours of operation.

278

279

280

281

282

283

284

285

286

287

288

289

290

291

292

293

294

295

296

297

298

299

300

301

302

303

304

305

\subsection{Environmental Monitoring}

During operation there were several aspects of environmental monitoring. Firstly the barge had a sonar unit (3 in Figure 5) mounted on the bow to record the depth and any incoming mammals, fish or flora. The sonar recorded the flow $2.5 D_{E}$ upstream from the turbine, so any potential collisions could be avoided by applying an electrical brake to the turbine. During operation there was always at least one person on the barge to monitor the turbine and to conduct mammal surveying. There was a full $360^{\circ}$ survey of the surrounding area every 15 minutes to check for mammals. Any sightings were recorded and a shut-down exclusion zone of 50m (visual) was implemented. An electrical brake was applied during shut-down. During the testing period there were 29 mammal sightings and 6 shut-down events. There is no evidence to suggest that mammals were harmed during the testing of the tidal turbine.

\section{Results}

\subsection{Data post-processing}

The data was collected synchronously at $10 \mathrm{~Hz}$ for the turbine, load cells and at $1 \mathrm{~Hz}$ for the inflow velocity. All post-processing was applied to data as per IEC technical specification [12, Section 9]; further detail and equations can be found in the reference document, though key equations will be presented here. No data filtering is permissible in the IEC standards [12, Clause 9.2.1]. The inflow velocity, denoted in later graphs as $U_{i n}$, was power-weighted across the rotor plane [12, Clause 9.3 - 9.7], as shown in Equations 1-7:

$$
\widehat{U}_{i, j, k}=\left[\frac{1}{A} \cdot \sum_{k=1}^{s} U_{i, j, k, n}^{3} \cdot A_{k}\right]^{1 / 3}
$$

where $A$ is the total projected capture area in $\mathrm{m}^{2}$ of the tidal energy converter; $A_{k}$ is the area in $\mathrm{m}^{2}$ of the $k^{\text {th }}$ current profiler bin through the projected capture area; $s$ is the total number of current profiler bins normal to the principal axis of energy capture across the projected capture area; $i$ is the subscript number defining the velocity bin number; $j$ is the subscript number of a time instant when the measurement is performed; $k$ is the subscript number of the current profiler bin; $n$ is the subscript number defining an individual data point in velocity bin $i$; 

profiler bin of the projected capture area.

308 The power weighted velocity was used for the assessment of instantaneous output power, but 309 the velocity, power and efficiency were binned by velocity. The mean bin equations for 310 velocity and active electrical power are given below:

$$
\begin{gathered}
\bar{U}_{i, n}=\left[\frac{1}{L} \cdot \sum_{j=1}^{L} \widehat{U}_{i, j, n}{ }^{3}\right]^{1 / 3} \\
\bar{P}_{i, n}=\left[\frac{1}{L} \cdot \sum_{j=1}^{L} P_{i, j, n}{ }^{3}\right]^{1 / 3} \\
\bar{U}_{i}=\frac{1}{N_{i}} \cdot \sum_{n=1}^{N_{i}} \bar{U}_{i, n} \\
\bar{P}_{i}=\frac{1}{N_{i}} \cdot \sum_{n=1}^{N_{i}} \bar{P}_{i, n}
\end{gathered}
$$

311

where $N_{i}$ is the number of data points in velocity bin $i$;

$\bar{P}_{i}$ is the mean recorded TEC power output in $\mathrm{W}$ in the $i^{\text {th }}$ velocity bin, denoted in later graphs and text as $P_{e l}$; $\bar{U}_{i}$ is the mean current velocity in $\mathrm{m} / \mathrm{s}$ in the $i^{\text {th }}$ velocity bin.

The vertical shear profile is also determined from the velocity data as described below:

$$
\begin{gathered}
\overline{\text { Ushear }}_{i, k, n}=\frac{1}{L} \cdot \sum_{j=1}^{L} U_{i, j, k, n} \\
\overline{\text { Sshear }}_{i, k}=\frac{1}{N_{k}} \cdot \sum_{n=1}^{N_{k}} \overline{\text { Ushear }}_{i, k, n}
\end{gathered}
$$

where $U_{i, j, k, n}$ is the magnitude of tidal current velocity flowing through the $k^{\text {th }}$ current profiler bin, as defined in equation (1); $L$ is the number of data samples in the defined averaging period which produces data point $n$;

$\overline{U s h e a r}_{i, k, n}$ is the mean current velocity data point flowing through current profiler bin $k$ over a given averaging period at a specific velocity increment, $i$; $N_{k}$ is the number of data points in current profiler bin $k$; $\overline{U s h e a r}_{i, k}$ is the mean recorded current velocity at current profiler bin $k$ in the $i^{\text {th }}$ velocity bin. 
328 The TEC efficiency was also determined, using the following formula:

$$
\eta_{\text {system }, i}=\frac{\bar{P}_{l}}{\frac{1}{2} \cdot \rho \cdot A \cdot \overline{U_{l}^{3}}}
$$

329

330

331

332

333

334

335

336

337

338

339

340

341

342

343

344

345

346

where $A$ is the total projected capture area in $\mathrm{m}^{2}$ of the tidal energy converter;

$\eta_{\text {system, } i}$ is the TEC overall efficiency in the $i^{\text {th }}$ current velocity bin;

$\bar{U}_{l}$ is the mean velocity in $\mathrm{m} / \mathrm{s}$ of the tidal current in current velocity bin $i$

$\bar{P}_{l}$ is the recorded electrical power output in $\mathrm{W}$ in current velocity bin $i$, denoted in later graphs and text as $P_{e l}$;

$\rho$ is the fluid density in $\mathrm{kg} / \mathrm{m}^{3}$, as defined in Subclause 9.1.1.

The load cell values were corrected for frame drag (measured in tests with no turbine blades attached) and the angle of the connecting wires to derive turbine thrust. Time series results were produced using the raw data and the time-averaged data sets were averaged as per [12, Clause 8.6]. The IEC suggests using an averaging period between 2 and 10 minutes; the data presented here has been $4 \mathrm{~min}$ averaged. 4 minute averages were found, in [5], to remove instantaneous data noise and provide consistent vertical flow profiles, so are suitable for data analysis purposes.

\subsection{Rotor shear profile}

Given the small diameter of the rotor the shear profile of the channel was not anticipated to affect the velocities across the capture area. Figure 11 shows the variation of the velocity across the rotor depth for 7 data sets.

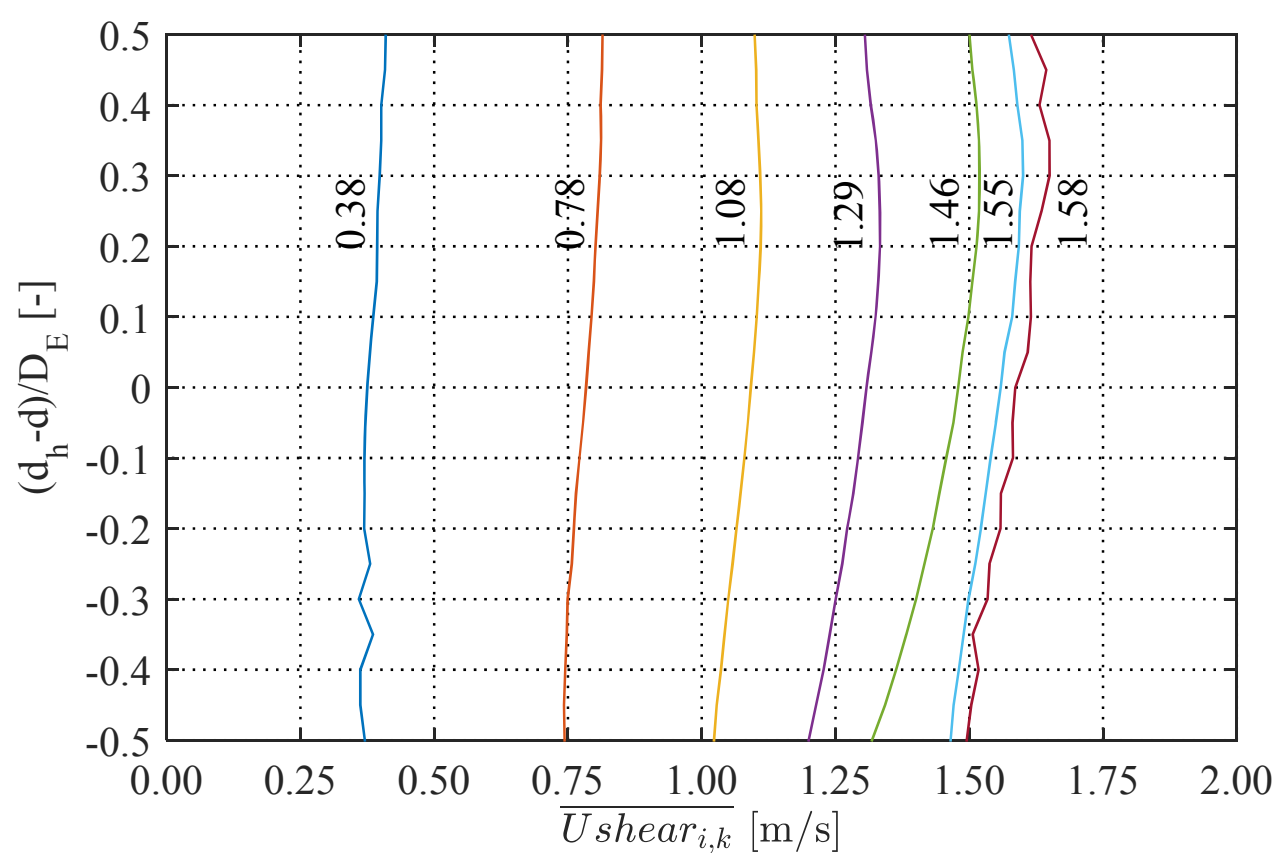


These represent the streamwise velocity across the 20 bins covering the rotor at banded velocities (as described in the equations above), with the power-weighted velocity given. A shear profile develops over the rotor area, with the shear typically becoming more pronounced with velocity. The difference between the lowest velocity, at the greater depth, and the power-weighted velocity is minimal. The average difference between the velocity at the lowest blade tip and the power-weighted velocity is $0.07 \mathrm{~m} / \mathrm{s}$. This small variation is only $3.5 \%$ of the rated power.

\section{6}

\subsection{Time series results}

The variations in the inflow velocity, electrical power, thrust, rotational speed and barge pitch during one flood cycle, on the $12^{\text {th }}$ July 2014, are shown below in Figure 11. These use 10s moving averages to show the variation with time.


The velocity can be seen to increase with time, until peak flood after 3 hours, then to decelerate until high water. Maximum flow occurs over a period of approximately 2 hours, though during this time the velocity can vary by up to $\pm 0.5 \mathrm{~m} / \mathrm{s}$, from $1.5 \mathrm{~m} / \mathrm{s}$ to $2.5 \mathrm{~m} / \mathrm{s}$, which is $25 \%$ of the mean velocity. 
The fluctuation in velocity appears to influence the other parameters, particularly the electrical power. The maximum fluctuation of the electrical power occurs at the instance of maximum flow, with power variations of $\pm 10 \mathrm{~kW}$, or $50 \%$ of the mean power. The fluctuation in power could result in differences from that predicted for the mean flow speed in steady state tests. The cut-in of the electrical power also occurs when there is a gust in the flow speed after approximately $25 \mathrm{mins}$ into the tide. This leads to cut-in velocity being exceeded and the power control starts. This gust that causes cut-in to be achieved is evident in the turbine RPM which shows a large acceleration in the rotational speed, until the control mechanism activates, reducing the shaft velocity due to the resistive load. Towards the end of the cycle, after 5 hours, the flow speed oscillates about the cut-in speed. This leads to short periods of high RPM when the PTO has not started, alternated with periods of lower RPM where power is produced, until the flow drops to a level where the turbine stops turning.

The thrust follows the same trend as the power, as the turbine is stopped, free turning, or operational. As flow and power increases, the thrust also increases. At maximum flow the variation in thrust is approximately $30 \%$ of the mean thrust, so is less significantly affected by the variation in flow than the power output. Particularly clear is the relationship between the power and the thrust during the last hour of the cycle. When the flow is below cut-in and the power is low, the thrust is also significantly reduced. The thrust on the frame and the turbine also result in the barge pitching. When there is no thrust on the structure the barge pitches at $-2^{\circ}$ and as the flow, and therefore thrust, increases the barge pitches forward up to $+3^{\circ}$. Since the ADP is attached to the same barge as the turbine, the pitch of the ADP is the same as that experienced by the turbine, so the correct inflow is recorded. Plus, the effective velocity in the streamwise plane is very similar to that experienced by the ADP/turbine because the pitch angles are so small, so no flow direction correction is applied.

390 The velocity fluctuations, that influence the other turbine parameters, can be quantified in terms of turbulence intensity, TI. This is defined as the fluctuating part of the velocity divided by the mean velocity:

$$
T I=\frac{U_{i n}{ }^{\prime}}{\overline{U_{l n}}}
$$

The turbulence intensity at hub height for each data set within each velocity band was calculated and the mean turbulence intensities at each velocity are shown in Figure 13. The turbulence intensity can be seen to decrease with velocity, indicating that the fluctuations about the mean reduce with velocity. The maximum $T I$ of $58 \%$ occurs at flow speeds of approximately $0.5 \mathrm{~m} / \mathrm{s}$, so below cut-in speed. At cut-in speed the $T I$ is approximately $40 \%$, which reduces down to $17 \%$ at $2.1 \mathrm{~m} / \mathrm{s}$. These large fluctuations in the incoming flow are inherent for tidal flows and are a consideration for device developers. Higher turbulence intensities could cause fatigue to the blades and affect performance, whereas lower turbulence intensities hinder wake recovery downstream from a turbine. Further investigation is required at all of the operational speeds to determine which turbulence intensities affect which turbine parameters, whether performance or fatigue related. Further analysis of the 
405 flow characteristics and the site measured using the ADP and MicroRider data at the test site 406 are presented in [16]; this gives an example of the conditions experienced at the test location.



407

Figure 13: Turbulence intensity at hub height for varying inflow velocities

408

4095.4 Time-averaged performance characteristics

410 The data for all of the testing period were $4 \mathrm{~min}$ time-averaged. The resulting maximum, 411 minimum, mean and standard deviation of the recorded TEC power, $P_{e l}$, are shown in Figure 412 14, plotted against the mean power-weighted inflow velocity (as per [12], Clause 10.7).

413 The results show that as the velocity increases the power increases exponentially, according 414 to the power curve. This curve follows the same trend as experienced in field pushing tests 415 [11], with cut-in power at approximately $0.8 \mathrm{~m} / \mathrm{s}$ and approximately $18 \mathrm{~kW}$ at $2 \mathrm{~m} / \mathrm{s}$. The 416 variation in the results, i.e. between $\max$ and $\mathrm{min}$, increases with velocity, potentially due to 417 the variation shown in Figure 12. The mean results are, however, consistent with those 418 predicted from previous tests [11]. The standard deviation in the results is expected to 419 increase until rated power is achieved; however, the rated inflow velocity for the STG turbine 420 is $2.75 \mathrm{~m} / \mathrm{s}$, which is not reached in these tests. 
421

422

423 The power results were separated into bins, as per [12, Clauses 9.3.1 and 10.8], and the mean 424

Figure 14: Scatter plot of electrical power output data recorded TEC power for each velocity bin is shown in Figure 15. This again shows the cut-in at $0.8 \mathrm{~m} / \mathrm{s}$ and the exponential increase in power with velocity. The maximum mean power achieved in these tests, using $4 \mathrm{~min}$ averages, was $19 \mathrm{~kW}$ at $2.05-2.1 \mathrm{~m} / \mathrm{s}$.
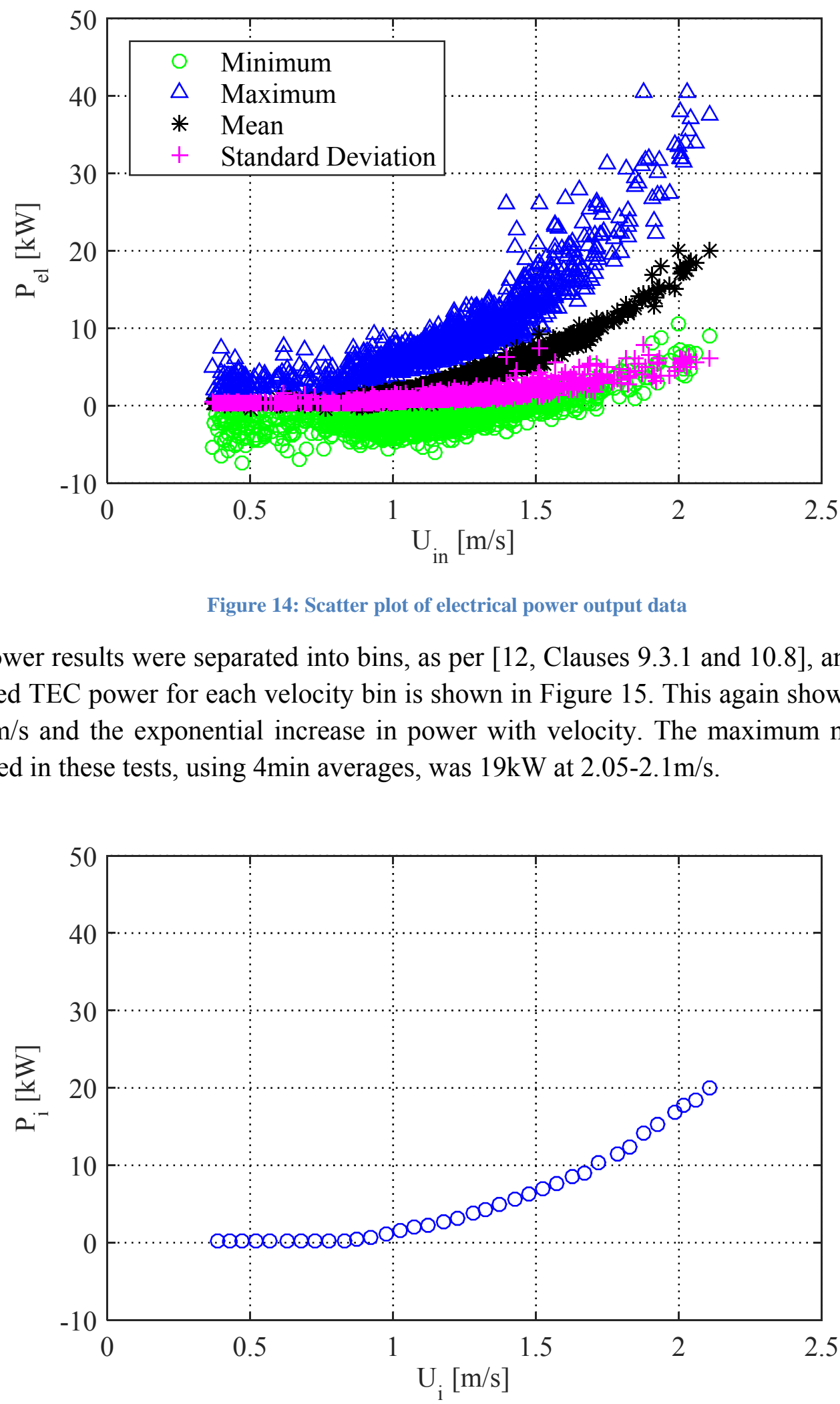

Figure 15: Mean electrical power output for each velocity bin

429 The overall TEC efficiency was calculated from the recorded electrical power. The efficiency 430 at varying inflow velocities is shown in Figure 16 (as per [12] Clause 10.9). Below cut-in the 431 efficiency is zero, but this increases with velocity. Above $1.2 \mathrm{~m} / \mathrm{s}$ the rate of improvement of 
432 efficiency decreases and above $1.5 \mathrm{~m} / \mathrm{s}$ the efficiency begins to plateau. Maximum efficiency 433 is expected at rated power; however, this could not be tested here since the maximum 434 velocities are limited at the current test site. For this data range maximum efficiency was $43534 \%$.

436

437

438 The thrust acting on the support strut and turbine were recorded. The thrust on the turbine 439 only, corrected for load angle and parasitic drag of the frame, against inflow velocity is 440 shown in Figure 17. The mean binned data, similar to that for power in Figure 15, is shown in 441 Figure 18. The thrust experiences a quadratic increase with velocity, as shown in [11].

442 The thrust on the turbine before cut-in is low, at approximately $0.5 \mathrm{kN}$. At maximum flow 443 speed between $2.05 \mathrm{~m} / \mathrm{s}$ and $2.1 \mathrm{~m} / \mathrm{s}$ the thrust acting on the turbine has increased to $17 \mathrm{kN}$. 444 This is consistent with the results from steady pushing tests [11], though the considerable 445

Figure 16: TEC overall efficiency curve

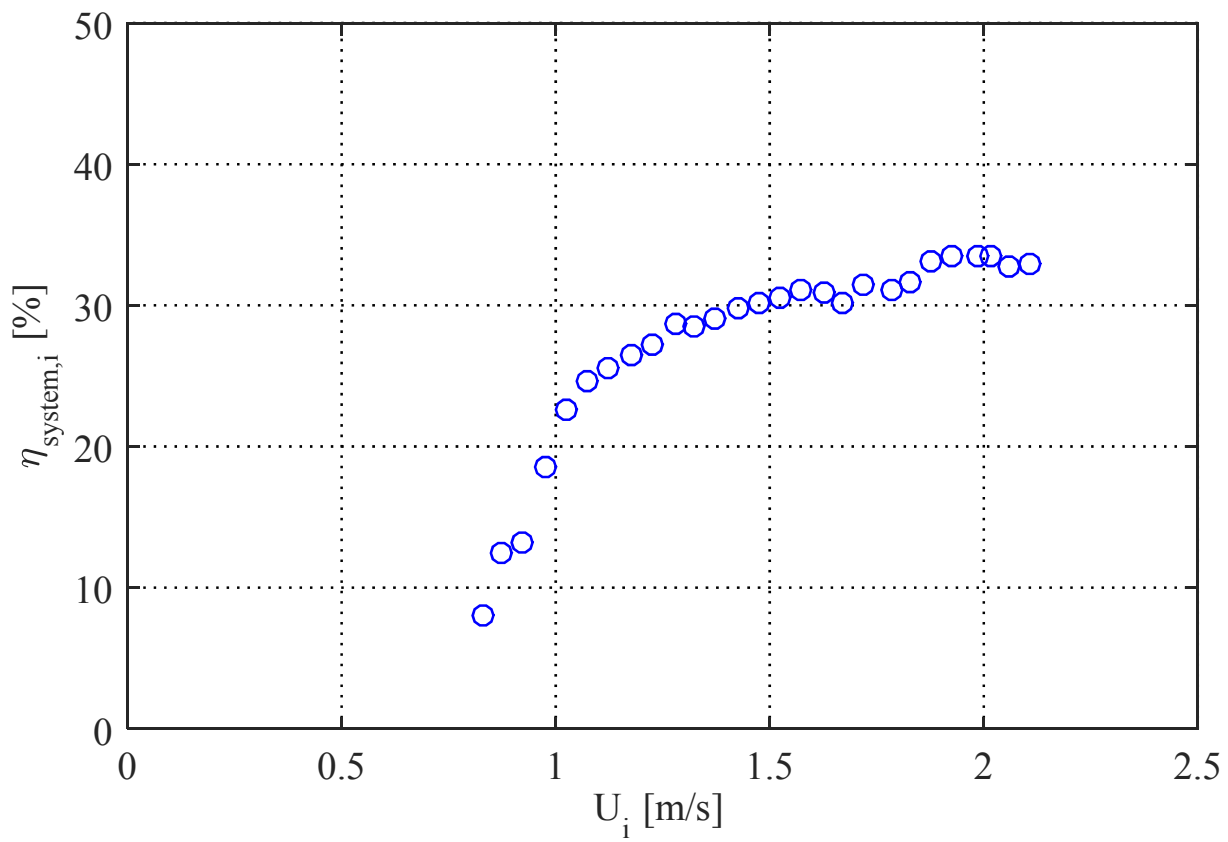


446

447

448

449

450

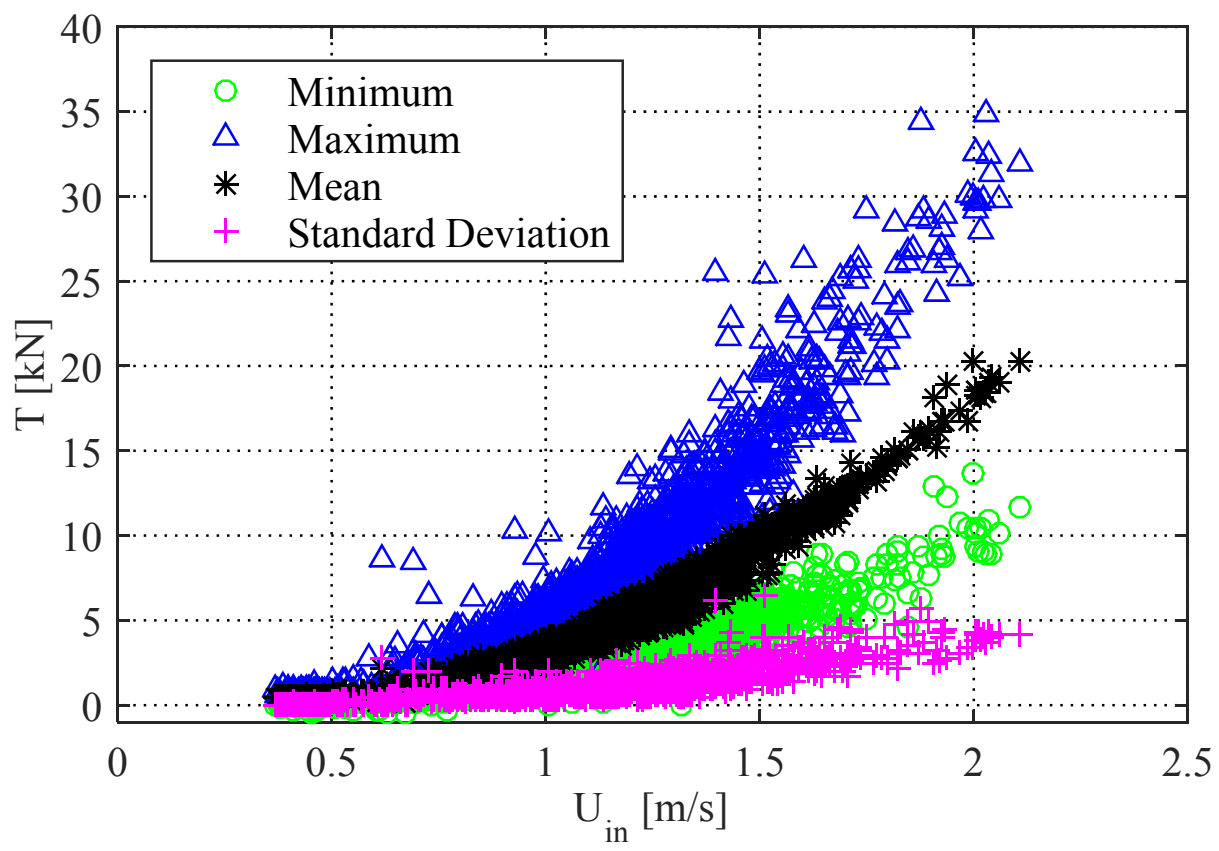

Figure 17: Scatter plot of thrust data

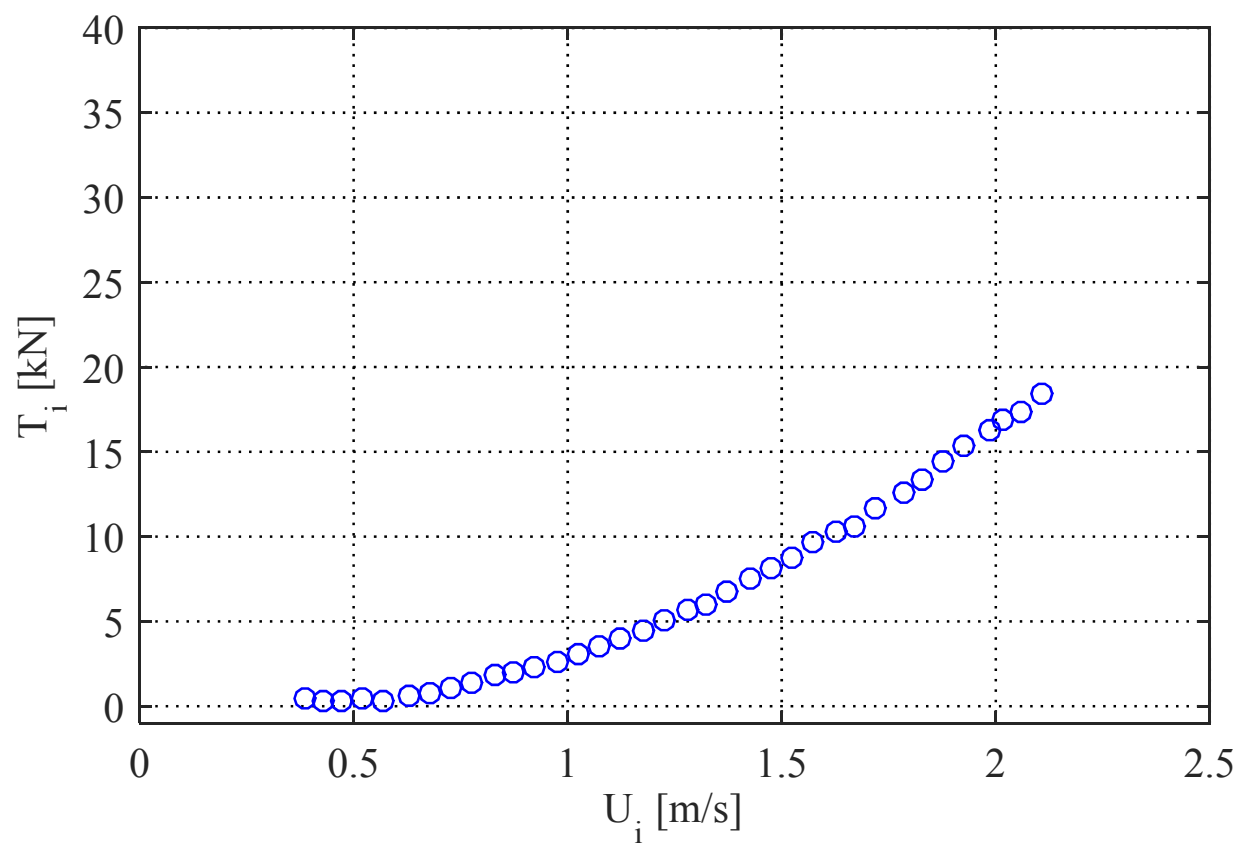

Figure 18: Mean thrust for each velocity bin 


\section{Conclusions}

452 Full-scale testing of the SCHOTTEL STG turbine has been undertaken at QUB's tidal test facility over a 4 month period in 2014. The key objective of the testing program was to test the full-scale turbine in real, tidal field flows. The key objectives of this paper are: to present a vessel-mounted testing method for field studies of medium- and full-scale tidal devices; to investigate the performance of a full-scale device in tidal flows; and to apply the IEC standards to data processing.

458 The tests were conducted in the QUB site, during flood, daylight hours for 48 days of testing, to collect 288 hours of data. The $4 \mathrm{~m}, 50 \mathrm{~kW}$ SCHOTTEL STG turbine was tested in flows between 0 and $2.5 \mathrm{~m} / \mathrm{s}$, to achieve time-averaged electrical power output up to $19 \mathrm{~kW}$. The testing method was therefore appropriate for testing a full-scale device at these flow speeds.

462

During the testing the turbine RPM, torque, mechanical power, electrical power and thrust were recorded. Simultaneously, the inflow velocity, turbulence (measured with 3 different instruments) and wake velocities were also recorded. The location, depth and mammal activity were also tracked. All the data was recorded and processed according to the IEC standards [12, Section 9].

467 The velocity, power, thrust and pitch curves produced were as expected, both time-varying and time-averaged. The fluctuations at maximum flow recorded were up to $25 \%$ of the mean for the velocity, $50 \%$ for the electrical power and 30\% for the thrust, showing significant variation of inflow conditions during testing. The maximum turbulence intensity recorded was approximately $58 \%$, though in the turbine operational range was between $40 \%$ and $17 \%$. The barge pitch during a testing cycle could vary up to $5^{\circ}$ as well. The maximum mean electrical power achieved during the entire testing period was $19 \mathrm{~kW}$ in flow speeds between 2.05 and $2.1 \mathrm{~m} / \mathrm{s}$. TEC efficiency reached $35 \%$ at $2.0-2.05 \mathrm{~m} / \mathrm{s}$. In the velocity range tested, as velocity increased so did power production and power efficiency, which also corresponded with reducing turbulence efficiency. The thrust was approximately $0.5 \mathrm{kN}$ when the turbine had not cut in, and reached $17 \mathrm{kN}$ in maximum flow. The data was all assessed to IEC standards.

During the testing campaign there were many more data sets collected, including turbulence and wake measurements. These will be analysed and published in due course. Further tests may include higher flow speed tests in similar flow, to reach rated velocity and power.

\section{Acknowledgements}

483 The author's would like to acknowledge the funding granted by the EU for the MaRINET 484 Access Program which allowed this work to be conducted. They would also like to acknowledge the funding granted by Invest Northern Ireland for the TTT2 project that supported this work. Many thanks also to the subcontractors and partners who worked on this project: Cuan Marine Services, ARR Ltd, Fraunhofer IWES, Oceanflow Energy, Joules 488 Energy Efficiency, McLaughlin and Harvey and the staff and students at both SCHOTTEL and QUB. 
491 [1] ScotRenewables scale model testing, http://www.scotrenewables.com/technology-

492 development/scale-model-testing Accessed 6th Oct 2014

493 [2] Oceanflow scale model testing. http://www.oceanflowenergy.com/development-

494 status.html Accessed 6th Oct 2014

495 [3] Andritz Hydro Hammerfest tidal testing,

496 http://www.hammerfeststrom.com/products/tidal-turbines/hs1000/ Accessed 6th Oct 2014

497 [4] Alstom TGL tidal testing, http://www.alstom.com/products-services/product-

498 catalogue/power-generation/renewable-energy/ocean-energy/tidal-energy/tidal-power/

499 Accessed 6th Oct 2014

500 [5] G. Savidge, D. Ainsowrth, S. Bearhop, N. Christen, B. Elsaesser, F. Fortune, R. Inger, R. 501 Knnedy, A. McRobert, K.E. Plummer, D. Pritchard, C.E. Sparling, T. Whittaker, Marine

502 Renewable Energy Technology and Environmental Interactions, M.A. Shields and A. Payne 503 (eds.), Springer

504 [6] Verdant Power KHPS tidal testing, http://www.verdantpower.com/kinetic-hydropower505 system.html Accessed 24th March 2015

506 [7] Atlantis Resources AR1000 tidal testing, http://atlantisresourcesltd.com/turbines/ar507 series/ar1000.html Accessed 24th March 2015

508 [8] Scotrenewables tidal testing. http://www.scotrenewables.com/250kw-prototype/sr250509 testing Accessed 6th Oct 2014

510 [9] L. Luznik, K.A. Flack, E.E. Lust, D.P. Baxter, Hydrodynamic performance of a 511 horizontal axis tidal turbine under steady flow conditions, Paper presented at Oceans, 512 Hampton Roads VA, 14-19 Oct 2012.

513 [10] P. Jeffcoate, B. Elsaesser, T. Whittaker, Testing tidal turbines - Part I: Steady towing 514 tests vs. Tidal Mooring Tests, Paper presented at ASRANet, Glasgow, UK, 15-17 Sept 2014.

515 [11] R. Starzmann, M. Baldus, E. Groh, N. Hirsch, N.A. Lange, S. Scholl, Full-Scale Testing 516 of a Tidal Energy Converter Using a Tug Boat, Paper presented at EWTEC, Aalborg, 517 Denmark, 2-5 Sept 2013.

518 [12] IEC/TS 62600-200. Marine energy - Wave, tidal and other water current converters 519 Part 200: Electricity producing tidal energy converters - Power performance assessment

520 [13] C.B. Boake, M. Atcheson, T.J.T. Whittaker, I.G. Bryden, Selection of a large model 521 scale field wave and tidal test site in Strangford Lough, UK, 1st International Conference on 522 Sustainable Power Generation and Supply (SUPERGEN) (2009) pp. 7

523 [14] R. Nicholls-Lee, Adaptive Composite Blades for Horizontal Axis Turbines, PhD thesis, 524 University of Southampton, 2011 
525 [15] R. Starzmann, M. Baldus, E. Groh, N. Hirsch, N.A. Lange, S. Scholl, A Stepwise 526 approach towards the development and full-scale testing of a marine hydrokinetic turbine, 527 Proceedings of the 1st Marine Energy Technology Symposium (METS13), April 10-11, 528 2013, Washington, D.C.

529 [16] H. Torrens-Spence, P. Schmitt, P. Mackinnon, B. Elsaesser, Current and Turbulence 530 Measurement with Collocated ADP and Turbulence Profiler Data, Presented at IEEE/OES

$53111^{\text {th }}$ Current, Wave and Turbulence Measurement Workshop, March 2-6, 2015, Florida, USA. 